\title{
IMPLICATIONS OF MONETARY UNION FOR CATCHING-UP MEMBER STATES
}


E UROPEANCENTRAL BANK

\section{WORKING PAPER SERIES \\ NO 630 / MAY 2006}

\section{IMPLICATIONS OF MONETARY UNION FOR CATCHING-UP MEMBER STATES '}

by Marcelo Sánchez ${ }^{2}$

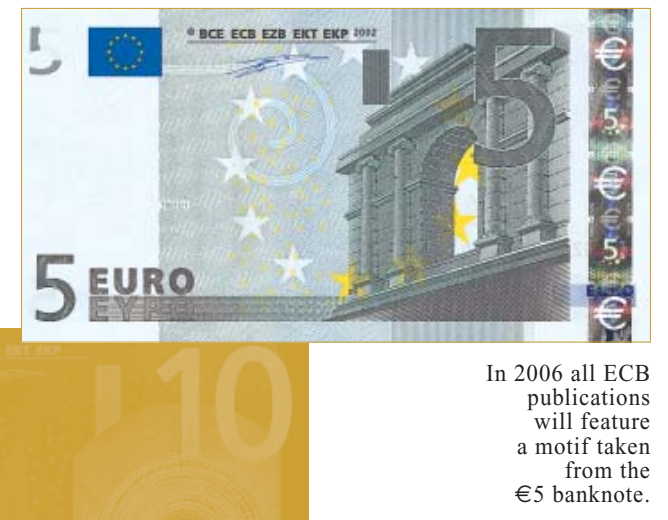

This paper can be downloaded without charge from http://www.ecb.int or from the Social Science Research Network electronic library at http://ssrn.com/abstract_id $=902535$ 
(C) European Central Bank, 2006

\section{Address}

Kaiserstrasse 29

60311 Frankfurt am Main, Germany

\section{Postal address}

Postfach 160319

60066 Frankfurt am Main, Germany

\section{Telephone}

+496913440

\section{Internet}

http://www.ecb.int

\section{Fax}

+496913446000

\section{Telex}

$411144 \mathrm{ecb} d$

All rights reserved.

Any reproduction, publication and reprint in the form of a different publication, whether printed or produced electronically, in whole or in part, is permitted only with the explicit written authorisation of the ECB or the author(s).

The views expressed in this paper do not necessarily reflect those of the European Central Bank.

The statement of purpose for the ECB Working Paper Series is available from the ECB website, http://www.ecb.int.

ISSN 1561-0810 (print)

ISSN 1725-2806 (online) 


\section{CONTENTS}

Abstract

Non-technical summary

1 Introduction

2 A simple model

2.1 Sectors and aggregation

2.2 Relative prices

2.3 Real exchange rate and sectoral productivity shocks

2.4 Nominal rigidity and aggregate supply

3 Autonomous monetary policy

4 The currency union

4.1 Determination of union-wide output and prices

4.2 Currency union's welfare

4.3 Reference member state's welfare

5 Relative performance and sensitivity analysis

5.1 Benchmark parameter values

5.2 Sensitivity analysis

6 Concluding remarks

Appendix: Solving for domestic output and

\section{prices under the currency union}

References

Figures

European Central Bank Working Paper Series 


\begin{abstract}
We examine the implications of monetary union for macroeconomic stabilisation in catching up participating countries. We allow member states'supply conditions to differ inside the union, especially with regard to sectoral characteristics. Sectoral productivity shocks on balance hamper the stabilisation properties of a currency union. In the face of aggregate supply disturbances, the stabilisation costs of renouncing monetary autonomy diminish with a flatter output-inflation tradeoff and - barring idiosyncratic shocks - with a larger reference country size, more homogeneous supply slopes and a higher preference for price stability.
\end{abstract}

JEL classification: E52; E58; F33; F40

Keywords: Monetary union, Balassa-Samuelson effect, Exchange rates, Price stability 


\section{Non-technical summary}

The experience and prospects of monetary integration around the world have attracted a wide-ranging literature over the last fifty years. The aim of this paper is to contribute to the theory of currency unions by examining the implications of the latter's monetary stabilisation policy for catching-up member states. Catching up economies tend to exhibit productivity-driven real appreciation processes of the type known as the Balassa-Samuelson effect. In order to account for this, we allow sectoral productivity shocks to influence real exchange rate movements. Moreover, currency unions comprising economies that are at different stages of the development process face challenges arising from structural differences among member states. With this in mind, we analyse scenarios that reflect plausible cross-country configurations concerning structural parameters and disturbances.

In order to compare a member state's welfare in a currency union to that under autonomous monetary policy, we set relative welfare at the value implied by benchmark structural parameter values. We then carry out sensitivity analysis with respect to parameter values with the aim of uncovering what determines stabilisation costs of renouncing monetary autonomy. Key parameters of our model include the slopes of the aggregate supply schedule and cross-country differences between them, countries' sizes, and the relative weights placed on price stability versus output stability in the monetary authority's objective function. Our approach is motivated by the notion that it is important to better understand the determinants of stabilisation costs, while at the same time recognising that a number of other factors play a key role in shaping a country's decision to enter a currency union. The latter factors prominently include the trade-enhancing effects of monetary union of the type found by Rose (2000) and other studies.

Our study of monetary policy in a currency union produces a number of different results. Sectoral productivity shocks are on balance found to ham- 
per the stabilisation performance of member states joining a currency union. We also assess the determinants of stabilisation costs in the face of aggregate supply disturbances. Our analysis shows that the output-inflation tradeoff and country size have welfare implications for a reference country. A flatter tradeoff between output and inflation is found to unambiguously contribute to an improvement of the currency union's stabilisation properties from the member state's point of view. In turn, a larger size also appears to have a rather favourable impact on the reference country's welfare under the currency union case, possibly excepting the case of a reference country mostly facing idiosyncratic disturbances while exhibiting a steep output-inflation tradeoff. Moreover, a higher cross-country spread in the slopes of the aggregate supply curve tends to favour currency union's member states with relatively flat tradeoffs between output and inflation. Finally, monetary unions that display a higher preference for price stability are found to also improve the stabilisation performance of member states, except in the event of idiosyncratic aggregate disturbances. 


\section{Introduction}

EU new member states from Central and Eastern Europe have in recent years gone through a rapid adjustment process as they approached entry into the EU. The pre-accession phase has been characterised by structural transformations of their economies, real exchange rate appreciation and rapid capital inflows. While these features are present in many emerging market economies (EMEs) as they catch up with industrial countries, new member states differ from those experiences in that they are expected to face special circumstances constraining domestic macroeconomic policies in their post-accession phase. In particular, fiscal instruments will have to comply with certain criteria, while prospects of participation in the euro zone may limit exchange rate fluctuations, especially in case they are or will become members of ERM II.

For this reason, it is understandable that some studies have analysed the policy options facing individual new member states in areas such as monetary and exchange rate policy (see, e.g., Devereux, 2003, and Natalucci and Ravenna, 2002). The present paper studies a different issue raised by the EU accession process, namely, the implications of a currency union's monetary stabilisation policy for catching-up member states. To do so, we distinguish between aggregate and sectoral productivity shocks. Sectoral productivity disturbances are allowed to account for real exchange rate movements, including the type of real appreciation processes known as the Balassa-Samuelson effect. ${ }^{1}$ Our model is similar to the one used by Ca' Zorzi et al. (2005) to investigate the decision of a country to enter a currency union, for which they derive analytical results. ${ }^{2}$ In addition, we derive results for scenarios that are reasonable for monetary unions comprising economies that are at different stages of the development process. In particular, we assess challenges posed to common

\footnotetext{
${ }^{1}$ This effect consists of the necessity of real exchange rate appreciation as a reaction to high productivity growth in the tradable sector relative to the non-tradable sector.

${ }^{2}$ Other contributions to the literature that are relevant for the present paper are Alesina and Barro (2002), and Benigno (2004).
} 
currency areas by structural differences among member states, as shown in country-specificities concerning structural parameters and disturbances. By bringing the dimensions of aggregate and sectoral productivity into the analysis, we aim at reaching a deeper understanding of the benefits and costs from monetary unions relative to autonomous monetary policy.

Given that issues raised by processes of structural change - including productivity-driven exchange rate developments - are important in many catching up countries, the insights provided by our analysis are not meant to be valid only for EU new member states, but among many EMEs more broadly. ${ }^{3}$ This includes countries for which monetary union is a real possibility in the near future (such as other countries in Central and Eastern Europe holding EU candidacy), as well as cases where currency unions remain a more prospective policy option discussed by analysts on a regular basis (such as EMEs in East Asia and Latin America). ${ }^{4}$ In connection with this, it is worth mentioning that the relevance of currency unions as a policy option has not been called into question by the recent debate about the optimality of exchange rate regimes. One strand of this literature has interpreted the instability of fixed exchange rate systems to imply that the only viable long-term options for a country are a floating exchange rate or participation in a currency union. This view, commonly known as the "hollowing-out hypothesis" was originally proposed by Fischer (2001). Alternatively, some authors have stressed that many officially pure floating regimes are in practice managed floats, thereby defying the

\footnotetext{
${ }^{3}$ Moreover, cross-country differences in structural parameters and the distribution of shocks are not restricted to the case of the catching up process. For instance, Romer (1993) argues and shows evidence that openness to international trade reduces equilibrium inflation by affecting two structural parameters, namely, the trade-off between output and inflation, and monetary authorities' relative weight on price stability.

${ }^{4}$ There is a considerable ongoing debate concerning the role of the Balassa-Samuelson effect in explaining real appreciation processes in fast-growing small open economies. See, e.g., Egert et. al. (2003), MacDonald and Wojcik (2004), Mihaljek and Klau (2004), De Broeck and Slok (2001) and Halpern and Wyplosz (2001) for Central and Eastern European countries, Sinn and Reutter (2001) for the euro area, and Devereux (1999) and Ito et. al. (1999) for the Asia region.
} 
notion that intermediate regimes are extinct. ${ }^{5}$ To the extent that the implied desire for relative exchange rate stability may be driven by regional competition considerations, this raises the question whether such stability could be best achieved by regional monetary cooperation and in particular a currency union. The latter arrangement could, if economically justified and properly designed, help maintain exchange rate stability while mitigating credibility problems sometimes arising in intermediate regimes. ${ }^{6}$

Other features of our approach are the following. First, we permit disturbances to adopt three different features, namely, to be common, idiosyncratic or asymmetric. This distinction is useful in drawing welfare implications from comparing monetary stabilisation properties of a currency union vis-à-vis a floating exchange rate arrangement. Second, we complement our analytical results with quantitative comparisons of stabilisation performance. We measure the latter by the loss function of the currency union's monetary authority relative to the alternative of autonomous monetary policy. Finally, we do sensitivity analysis with respect to key structural parameters, including the slopes of the aggregate supply schedule, countries' sizes, and the weight placed on price stability versus output stability in the monetary authority's objective function. ${ }^{7}$ In doing so, we permit in our simulations a key structural parameter (the supply slope parameter) to differ across countries.

The structure of the rest of the paper is as follows. In section 2, the model is laid out. As a prelude to the analysis of a currency union, we analyse optimal monetary policy under the alternative of autonomous monetary policy

\footnotetext{
${ }^{5}$ Some of the skeptics have pointed to a "fear of floating" whereby countries that declare themselves floaters nevertheless intervene regularly to prevent full flexibility of the exchange rate. The key paper in this area is Calvo and Reinhart (2002). In parallel, a related literature has recently proposed de facto exchange regime classifications as opposed to IMF-type de jure ones (see, e.g., Reinhart and Rogoff, 2004).

${ }^{6}$ The idea of joining a currency union as a commitment strategy has been developed in Alesina and Barro (2002).

${ }^{7}$ Lane (2000) performs sensitivity analysis with respect to key parameter values in a twocountry model. Our approach differs from his in that the focus here is on the implications of monetary integration for member countries, rather than of the stabilisation performance of the currency union itself. For related work, see Sánchez (2005a and 2005b).
} 
in section 3. In section 4, we present analytical results for monetary policy in a currency union. Section 5 develops the quantitative comparative results on stabilisation performance and sensitivity analysis. Section 6 concludes.

\section{A simple model}

In order to investigate monetary stabilisation properties of a currency union, we set up a simple model that distinguishes between aggregate and sectoral productivity shocks. In the present setting, such sectoral shocks contribute to determine the behaviour of real exchange rates. Moreover, monetary nonneutrality, introduced by having the nominal wage set prior to the realisation of shocks, is used to derive the aggregate supply schedule.

\subsection{Sectors and aggregation}

Let us define a fast growing small open economy as country $h$ and its larger partner $f$. Both economies produce traded $(\mathrm{T})$ and non-traded $(\mathrm{N})$ goods. We use the following indices for countries and sectors, respectively: $i=h ; f$ and $k=T ; N$. The model is in logs and all variables are interpreted as growth rates unless stated otherwise. All variables are expressed in logarithms. All parameters are assumed to be positive. All shocks are of the zero-mean, constant variance type. They are also assumed to be uncorrelated with each other for each economy $i$, but allowed to be correlated across countries, as is made clear below.

Output can be aggregated over traded and non-traded sectors as follows:

$$
y_{i}=\gamma_{i} y_{i}^{T}+\left(1-\gamma_{i}\right) y_{i}^{N}
$$

where $\gamma_{i}$ denotes the share of the traded goods in real output. Consistently with this specification, the price level is given by a weighed average of the 
price of traded goods, $p_{i}^{T}$, and the price of non-traded goods, $p_{i}^{N}$ :

$$
p_{i}=\gamma_{i} p_{i}^{T}+\left(1-\gamma_{i}\right) p_{i}^{N}
$$

while demand for sectoral output is assumed to depend only on relative prices:

$$
y_{i}^{k}-y_{i}=-\left(p_{i}^{k}-p_{i}\right)
$$

\subsection{Relative prices}

Sectoral output is produced using a standard Cobb-Douglas technology:

$$
y_{i}^{k}=a_{i}^{k}+\beta_{i}^{k} l_{i}^{k}
$$

where $a_{i}^{k}$ is sector- $k$ total factor productivity and $l_{i}^{k}$ is sector- $k$ employment while $\beta_{i}^{k} \in(0,1)$. Aggregating over sectors gives:

$$
y_{i}=a_{i}+\gamma_{i} \beta_{i}^{T} l_{i}^{T}+\left(1-\gamma_{i}\right) \beta_{i}^{N} l_{i}^{N}
$$

where $a_{i} \equiv \gamma_{i} a_{i}^{T}+\left(1-\gamma_{i}\right) a_{i}^{N}$ measures aggregate total factor productivity in country $i$. The sectoral demands for labour are derived by equating the marginal product of labour to the producer real wage:

$$
l_{i}^{k}=p_{i}^{k}+y_{i}^{k}-w_{i}
$$

where $w_{i}$ is the nominal wage rate, which is equalised across sectors. The latter expression can be re-arranged as follows:

$$
p_{i}^{N}-p_{i}^{T}=\left(y_{i}^{T}-l_{i}^{T}\right)+\left(y_{i}^{N}-l_{i}^{N}\right)
$$

If productivity growth in the traded sector is greater than in the non-traded sector, the relative price for non-traded goods increases. This is the way the 
Balassa-Samuelson effect shows in relative prices between the two sectors of the economy. ${ }^{8}$ In the next subsection we discuss Balassa-Samuelson effect in the context of real exchange rate determination.

One corollary from (3) and (7) is that employment is uniform across sectors, that is, $l_{i}^{T}=l_{i}^{N}=l_{i}$. Using this result, alongside (4) and (7), yields:

$$
p_{i}^{N}-p_{i}^{T}=\left(a_{i}^{T}-a_{i}^{N}\right)+\left(\beta_{i}^{T}-\beta_{i}^{N}\right) l_{i}
$$

\subsection{Real exchange rate and sectoral productivity shocks}

Let us define $q_{i}^{T}$ to be the relative tradable price between countries $i$ and $f$ in country $i$ 's currency. If $s$ is the nominal exchange rate (the amount of country $h$ 's currency per unit of $f$ 's currency), the definition of $q_{i}^{T}$ implies that $q_{h}^{T}=p_{f}^{T}+s-p_{h}^{T}$, which can be interpreted as a deviation from the law of one price between our two countries. ${ }^{9}$ Moreover, by construction $q_{f}^{T}=0$. Using these expressions, together with (2) and (8), we obtain

$$
\begin{aligned}
& p_{h}=p_{f}^{T}+s+\theta_{h} \\
& p_{f}=p_{f}^{T}+\theta_{f}
\end{aligned}
$$

where $\theta_{i} \equiv\left(1-\gamma_{i}\right)\left[\left(a_{i}^{T}-a_{i}^{N}\right)+\left(\beta_{i}^{T}-\beta_{i}^{N}\right) l_{i}\right]-q_{h}^{T}$. Furthermore, the real exchange rate can be defined as $e=p_{f}+s-p_{h}$. Note that a fall in $e$ represents a real appreciation for country $h$. Using the latter two definitions, together with (9) and (10), we can express the real exchange rate as $e=-\left(\theta_{h}-\theta_{f}\right)$.

\footnotetext{
${ }^{8}$ It is worth saying that perfect labour mobility across sectors may fail to hold in the short-run. Compared with the analysis pursued here, that would weaken the power of the Balassa-Samuelson effect at the cyclical frequency that is relevant for analysis of monetary policy.

${ }^{9}$ Failure of the law of one price to hold, even if we assume a single traded good internationally, can be rationalised in terms of cross-border frictions. The literature has given several explanations for this, including transaction costs and imperfect information. Some papers have stressed that, even if the law of one price were to hold at the docks, the observed retail price would deviate from the world price because of (non-traded) domestic inputs in the chain of distribution of tradable goods (Burstein et al., 2003), or failure of the CPI measure to capture quality adjustments of tradable goods (Burstein et al., 2005).
} 
The latter expression, together with the definition of $\theta_{i}$, leads to:

$$
e=-\left(1-\gamma_{h}\right)\left[\left(a_{h}^{T}-a_{h}^{N}\right)+\left(\beta_{h}^{T}-\beta_{h}^{N}\right) l_{h}\right]+\left(1-\gamma_{f}\right)\left[\left(a_{f}^{T}-a_{f}^{N}\right)+\left(\beta_{f}^{T}-\beta_{f}^{N}\right) l_{f}\right]+q_{h}^{T}
$$

From (11), one observes that there are four forces contributing to determine the real exchange rate. Let us analyse these four forces in turn for the case of a decrease in $e$. First, a real appreciation would, ceteris paribus, result from a higher differential between $h$ and $f$ in total factor productivity in the tradable relative to the non-tradable sector. That is, if $\left(a_{h}^{T}-a_{h}^{N}\right)>\left(a_{f}^{T}-a_{f}^{N}\right)$. This is the form that the Balassa-Samuelson effect takes in our model. This effect depends on assumptions regarding the other three forces driving real exchange rates. ${ }^{10}$ Second, a real appreciation would obtain if one of the two countries exhibits positive differentials with respect to the other in the product of the two following factors: a) deviations in employment from steady state $\left(l_{i}\right)$, and b) the gap between the elasticities of sectoral output with respect to labour in the tradable sector and that in the non-tradable sector $\left(\beta_{i}^{T}-\beta_{i}^{N}\right)$. That is, if $\left(\beta_{h}^{T}-\beta_{h}^{N}\right) l_{h}>\left(\beta_{f}^{T}-\beta_{f}^{N}\right) l_{f}$. Third, the former two forces would be amplified by a differential degree of openness in country $f$ 's favour, that is, if $\gamma_{h}<\gamma_{f}$. Fourth, a real appreciation would result from a deviation from the law of one price between our two countries, that is, if $q_{h}^{T}>0$.

We shall below relate fluctuations in $e$ to sectoral productivity shocks. For this purpose, it is useful to group the latter shocks hitting country $i$ in the disturbance $\tau_{i}$, which we define as a shock to variable $\theta_{i}$, that is, $\tau_{i} \equiv \theta_{i}-E\left(\theta_{i}\right)$, where $E\left(\theta_{i}\right)$ denotes the unconditional expectation of $\theta_{i} .{ }^{11}$ Finally, unexpected developments in exchange rates are described by $\tau_{e} \equiv-\left(\tau_{h}-\tau_{f}\right)$. In what follows, we shall interpret changes to $\tau_{e}$ as driven by sectoral productivity

\footnotetext{
${ }^{10}$ In particular, the Balassa-Samuelson effect obtains under the following "neutral" (sufficient) conditions: i) $\gamma_{h}=\gamma_{f}$; ii) $\beta_{h}^{T}-\beta_{h}^{N}=\beta_{f}^{T}-\beta_{f}^{N}$; and iii) $q_{h}^{T}=0$.

${ }^{11}$ In what follows, $E(x)$ denotes the unconditional expectation of any variable $x$.
} 
shocks in country $h$ relative to $f$, that is, as a stochastic Balassa-Samuelson effect. ${ }^{12}$

\subsection{Nominal rigidity and aggregate supply}

We introduce nominal wage rigidity by assuming that in each country the economy-wide nominal wage is set so as to minimise the expected deviation of aggregate employment $l_{i}$ from its long run flexible-wage level $\bar{l}_{i}$. Moreover, labour supply is assumed to be perfectly inelastic in the long run, more concretely at $\bar{l}_{i}=0$. In this context, when setting the nominal wage $w_{i}$ prior to the realisation of shocks, the trade union expects $E\left(\bar{l}_{i}\right)=0$, which implies $E\left(y_{i}\right)=E\left(a_{i}\right)$ from aggregating over (3). Furthermore, aggregating over (6), the optimal wage rate satisfies $w_{i}=E\left(p_{i}\right)+E\left(y_{i}\right)$. We implicitly assume that workers are prepared to meet any demand for labour required by firms after the realisation of shocks. Given (3), (6) and the expression for $w_{i}$ just obtained, the aggregate supply schedule obtains:

$$
y_{i}=\bar{y}_{i}+\alpha_{i}\left[p_{i}-E\left(p_{i}\right)\right]+\varepsilon_{i}
$$

where $\bar{y}_{i}=E\left(y_{i}\right)=E\left(a_{i}\right)$ is the natural output level of the economy, $\alpha_{i} \equiv$ $\phi_{i} /\left(1-\phi_{i}\right)$ is the slope of the supply curve, $\varepsilon_{i} \equiv\left[a_{i}-E\left(a_{i}\right)\right] /\left(1-\phi_{i}\right)$ is the aggregate supply shock, and $\phi_{i} \equiv \beta_{i}^{T}+\gamma_{i}\left(\beta_{i}^{T}-\beta_{i}^{N}\right)$. Parameter $\alpha_{i}$ is likely to reflect cross-country differences in economic structure among countries. In particular, it has been argued that trade openness, by raising the exchangerate pass-through effect on prices of a given economic expansion, makes the tradeoff between output and inflation flatter (Romer, 1993; Lane, 1997). ${ }^{13}$ Taken literally, this would imply a negative link between coefficients $\gamma_{i}$ and $\alpha_{i}$ in our model. For this to happen, taking into account both the positive link

\footnotetext{
${ }^{12}$ It is worth mentioning, however, that another factor determining $\tau_{e}$ are violations in the law of one price, as captured by $q_{h}^{T}$.

${ }^{13}$ This relationship between openness and the aggregate supply slope has recently been challenged by Temple (2002). Barry (2001) shows that the relationship still holds under monopolistic competition in the non-tradable sector.
} 
between $\alpha_{i}$ and $\phi_{i}$ and the latter's definition, we need that $\beta_{i}^{N}>\beta_{i}^{T}$. This result is not surprising, in light of our discussion surrounding expression (11). Indeed, the inequality $\beta_{i}^{N}>\beta_{i}^{T}$ means that, other things equal, the country's tradable sector's productivity is not as high as in the non-tradable sector. This contributes to an exchange rate depreciation and thus - in a context of larger trade openness - to a flatter output-inflation tradeoff.

It is worth mentioning that trade openness is also sometimes seen as being inversely related to country size. Many studies have found that smaller economies tend to be more open to international trade, while the world's largest countries (topped by the US and Japan) are rather closed in terms of trade to GDP ratios. Alesina et al. (2005) summarise the arguments and the evidence about the link in question. They find that trade openness, by enhancing the magnitude of the market facing a given country, increases the benefits of small size. Conversely, small countries have a strong interest in maintaining access to international markets (including via multilateral and regional means). We shall later assess our results having the relationship between size and openness in mind. Lacking a precise estimate of the correlation between these two variables, though, constrains us to a purely qualitative evaluation in this area.

\section{Autonomous monetary policy}

Under this regime, the monetary authority chooses its policy independently at the country level. Under discretion, the central bank minimises a loss function given by ${ }^{14}$

$$
L_{i}=\frac{1}{2}\left[\left(y_{i}-\bar{y}_{i}\right)^{2}+\chi_{i}\left(p_{i}-\tilde{p}_{i}\right)^{2}\right]
$$

\footnotetext{
${ }^{14}$ Modern research in macroeconomics shows that quadratic loss functions such as (13) here can be, under certain conditions, interpreted as a second order approximation to the welfare of the representative agent (see, e.g., Woodford, 2003),. The present paper makes the standard simplifying assumption that the marginal rate of substitution between the target is independent of the economic structure. This assumption is however relaxed in the context of optimising frameworks.
} 
The policymaker thus care about deviations of aggregate output and prices from the targets, as given by $\bar{y}_{i}$ and $\tilde{p}_{i}$, respectively. For simplicity, we assume that $\tilde{p}_{i}$ adopts a fixed and credible value. In the present context, the central bank has no incentive to surprise the private sector with inflation. In consequence, there is no inflation bias. Parameter $\chi_{i}$ denotes the central bank's relative weight of price stability versus output stability.

We assume that country $i$ 's public knows $\alpha_{i}, \chi_{i}, \tilde{p}_{i}$, as well as the distribution of the aggregate and sectoral productivity disturbances underlying $\varepsilon_{i}$ and $\tau_{i}$ for all $i$. We also assume that the central bank and firms observe current output, prices and nominal exchange rates. With this information, and knowledge of the structure of the model, they are in a position to deduce the sources of the shocks that hit the economy.

To solve the model, it is convenient to think of the central bank as choosing $p_{i}$ to minimise its loss function. Optimisation, after imposing rational expectations and using our simplifying assumption that $\tilde{p}_{i}$ is fixed and credible, implies that $E\left(p_{i}\right)=\tilde{p}_{i}$. This result can be used to express optimal output and prices as follows:

$$
\begin{aligned}
& y_{i}=\bar{y}_{i}+\frac{\chi_{i}}{\alpha_{i}^{2}+\chi_{i}} \varepsilon_{i} \\
& p_{i}=\tilde{p}_{i}-\frac{\alpha_{i}}{\alpha_{i}^{2}+\chi_{i}} \varepsilon_{i}
\end{aligned}
$$

where deviations of output and prices from target are shown to respond only to aggregate supply shocks.

Replacing (14) and (15) into (13), we can express the loss function as

$$
L_{i}=\frac{1}{2} \frac{\chi_{i}}{\alpha_{i}^{2}+\chi_{i}} \varepsilon_{i}^{2}
$$




\section{The currency union}

In the case where countries $h$ and $f$ form a monetary union, we assume that the central bank minimises a loss function given by

$$
L_{u}=\frac{1}{2}\left[\left(y_{u}-\bar{y}_{u}\right)^{2}+\chi\left(p_{u}-\tilde{p}_{u}\right)^{2}\right]
$$

where $u$ denotes the monetary union regime. ${ }^{15}$ In (17), the objective function of the central bank penalises departures of union-wide output and prices from desired values set to $\bar{y}_{u}$ and $\tilde{p}_{u}$, respectively. In resemblance to the countrylevel analysis of the previous section, we assume that the union's public knows $\alpha_{i}, \chi, \tilde{p}_{i}$, as well as the distribution of the aggregate and sectoral productivity disturbances underlying $\varepsilon_{i}$ and $\tau_{i}$ for all $i$. The remaining informational assumptions are also analogous to those used in the last section.

Before we turn to the solution of the model, let us define different types of shocks according to their distribution across the union. This will be needed when interpreting the results and doing welfare analysis. In the case of aggregate supply shocks, we examine the three types of shocks, namely: (i) asymmetric; (ii) idiosyncratic; and (iii) common. Shocks are normalised to be of unit magnitude for country $h$, which is - without loss of generality - the focus of our comparisons across regimes. Asymmetric shocks are defined to be shocks such that they add up to zero at the currency union level; in particular, country $h$ of size $\varphi$ is assumed to face a shock equal to 1 , while country $f$ faces a shock equal to $-\varphi /(1-\varphi)$. Idiosyncratic shocks are those in which shocks to country $h$ equal 1 , and shocks to country $f$ equal 0 . Finally, common shocks are defined to be shocks such that both countries face a shock equal to 1 .

In the case of sectoral productivity disturbances affecting $\tau_{i}$ and contributing to impact the exchange rate between $h$ and $f$, we take into account that the variable $\tau_{e}$ has a relative connotation that is absent in $\varepsilon_{i}$. The common

\footnotetext{
${ }^{15}$ Union-wide variables are weighted averages using weights $\varphi \in(0,1)$ for country $h$ and $1-\varphi$ for country $f$.
} 
sectoral productivity shock has no (relative) effect at the union level, which is achieved by assuming that both countries $h$ and $f$ face a shock equal to 1. As with aggregate shocks, the idiosyncratic disturbance takes place when only country $h$ is hit (by a disturbance $\tau_{h}$ equal to 1 ). Finally, in the case of a asymmetric sectoral productivity shock, country $h$ faces a shock $\tau_{h}$ equal to 1 , while country $f$ faces a shock $\tau_{f}$ equal to $-1 .^{16}$

\subsection{Determination of union-wide output and prices}

To solve the model, let us start by taking averages over (12), which yields

$$
y_{u}=\alpha_{u}\left[p_{u}-E\left(p_{u}\right)\right]+\varepsilon_{u}+\Omega
$$

where $\Omega \equiv \varphi\left(\alpha_{h}-\alpha_{u}\right)\left[p_{h}-E\left(p_{h}\right)\right]+(1-\varphi)\left(\alpha_{f}-\alpha_{u}\right)\left[p_{f}-E\left(p_{f}\right)\right]$. We next replace (18) into (17), differentiate with respect to $p_{u}$ to get the firstorder condition and impose rational expectations. As a result, we derive an expression for the optimal price level:

$$
p_{u}=\tilde{p}_{u}-\frac{\alpha_{u}}{\alpha_{u}^{2}+\chi}\left(\varepsilon_{u}+\Omega\right)
$$

where we have also used the result that $E\left(p_{u}\right)=\tilde{p}_{u}$.

Using (18) and (19), alongside (9), (10) and the definition of $\tau_{e}$ at the end of subsection 2.3 , we obtain:

$$
\begin{aligned}
& y_{u}=\bar{y}_{u}+\frac{\chi}{\alpha_{u}^{2}+\chi}\left[\varepsilon_{u}-\varphi(1-\varphi)\left(\alpha_{h}-\alpha_{f}\right) \tau_{e}\right] \\
& p_{u}=\tilde{p}_{u}-\frac{\alpha_{u}}{\alpha_{u}^{2}+\chi}\left[\varepsilon_{u}-\varphi(1-\varphi)\left(\alpha_{h}-\alpha_{f}\right) \tau_{e}\right]
\end{aligned}
$$

Equations (20) and (21) indicate that union-wide output and prices hover around their targeted values. Unexpected developments in each of the two

\footnotetext{
${ }^{16}$ In consequence, $\tau_{e}$ equals 0 under a common shock, -1 under an idiosyncratic shock, and -2 under an asymmetric shock.
} 
countries contribute to determine $y_{u}$ and $p_{u}$. In particular, judging from the aggregate supply shocks in $\varepsilon_{u}$, the second terms in (20) and (21) reflect the following mechanism: if country $i$ is subjected to such disturbances the reaction of union-wide output and inflation will be increasing in the size of that country ( $\varphi$ in the case of country $h$ and $1-\varphi$ in the case of $f$ ).

\subsection{Currency union's welfare}

Use of (20) and (21) leads to a new expression for the realised loss function (17) at the optimum:

$$
L_{u}=\frac{A}{2}\left[\varepsilon_{u}-\varphi(1-\varphi)\left(\alpha_{h}-\alpha_{f}\right) \tau_{e}\right]^{2}
$$

where $A \equiv \chi /\left(\alpha_{u}^{2}+\chi\right)$. When shocking the currency union's economies, we do so in ways that aggregate disturbances $\varepsilon_{u}$ and sectoral shocks $\tau_{e}$ are uncorrelated with each other. In this way, we can isolate the individual impact of each shock. Moreover, it is worth saying that aggregate and sectoral productivity disturbances have the following properties in terms of the cross-country covariances. An asymmetric shock implies a negative such covariance between countries $h$ and $f$, an idiosyncratic shock amounts to a zero covariance between the two countries, and a common shock means that the covariance between countries $h$ and $f$ is 1 .

The single monetary authority's welfare loss function $L_{u}$ is not the focus of our analysis, which instead lies with the reference country $h$ 's welfare. However, the analysis of $L_{u}$ indirectly sheds light on the latter in light of the relevant impact of monetary policy actions on country $h^{\prime}$ s economy under the currency union. In (22), the cross-country distribution of aggregate and sectoral supply disturbances affects the union's realised welfare loss in $L_{u}$ in a way that depends on specific parameter values. Under idiosyncratic aggregate productivity shocks a small catching up economy would have a limited 
impact on the union unless the country's aggregate supply variability is very large. Taking as a benchmark the case when the supply slope parameter is uniform across the union, sectoral productivity disturbances fail to have an impact on welfare. Supply slope parameters are likely to exhibit cross-country variation if member states are at different stages in the development process. In this case, idiosyncratic and asymmetric sectoral supply disturbances are found to hamper a currency union's stabilisation performance, while common shocks instead exhibit a built-in dampening factor, thereby enhancing the case for monetary stabilisation in a common currency area. Both country-specific output-inflation tradeoffs and the occurrence of idiosyncratic or asymmetric shocks are arguably more likely in the presence of catching up member states.

\subsection{Reference member state's welfare}

The focus of our analysis is the comparison between country $h$ 's welfare under autonomous monetary policy $\left(L_{h}\right.$ in (16)) and its welfare as a member state. The latter is captured by the loss function

$$
L_{h}^{u}=\frac{1}{2}\left[\left(y_{h}^{u}-\bar{y}_{h}\right)^{2}+\chi_{i}\left(p_{h}^{u}-\tilde{p}_{h}\right)^{2}\right]
$$

where $y_{h}^{u}$ and $p_{h}^{u}$ are the values adopted by $h$ 's output and prices under currency union participation. The values of $y_{h}^{u}$ and $p_{h}^{u}$ can be determined as follows. In case supply slope parameter $\alpha_{i}$ displays cross-country variation, those values can be found - alongside the corresponding values for country $f$, $y_{f}^{u}$ and $p_{f}^{u}$, for a total of four unknowns - by solving the following four equations: two national supply curves (12) for $i=h ; f$, and the pair of expressions (20) and (21). ${ }^{17}$ Given that we focus on the perspective of a catching up country, a scenario of common supply slopes $\alpha_{i}$ appears to be relatively less likely. Moreover, it is worth admitting that this case also proves somewhat more difficult to formalise, as we discuss in the Appendix. In what follows, we concentrate on the case of country-specific output-inflation tradeoffs.

\footnotetext{
${ }^{17}$ The Appendix presents these equations in more detail.
} 


\section{$5 \quad$ Relative performance and sensitivity analysis}

Following the qualitative results found in the previous section, we now turn to the quantitative analysis of a member state's welfare in a currency union relative to that in the autonomous monetary policy case. In doing so, we aim at gauging how sensitive are the performance differences between regimes to variations in key parameter values.

The first distinction to be drawn is that between aggregate and sectoral productivity shocks. ${ }^{18}$ The latter do not enter the reference country $h$ 's welfare function (16) under monetary autonomy. Neither do sectoral shocks affect the reference country's welfare under the currency union when they are common, given that in this case the single monetary authority does not react. However, disturbances in $\tau_{e}$ have an adverse effect on $h$ 's welfare (23) when they are asymmetric or idiosyncratic. The reason is that such types of shocks elicit reactions from the monetary union's central bank that would (optimally) be absent under monetary autonomy. The latter scenarios of asymmetric and idiosyncratic disturbances make the difference, with autonomous monetary policy thus outperforming its alternative under sectoral shocks. Unlike the latter, aggregate supply shocks enter countries' welfare loss function both under monetary autonomy and the currency union. This also makes the comparative assessment of the performance of each regime particularly involved, with neither autonomous monetary policy nor the currency union clearly outperforming its alternative. We turn to this analysis in subsection 5.2, after setting up baseline parameter values in subsection 5.1 .

\footnotetext{
${ }^{18}$ The relationship between aggregate and sectoral productivity shocks is little understood. Jiménez-Rodríguez and Sánchez (2005) show empirically that an adverse supply disturbance (an oil price shock to advanced net oil importing economies) induces different reactions in real exchange rates. In particular, the real exchange rate appreciates in some countries (such as the US and Germany) while it depreciates in others (such as other euro area countries and Japan).
} 


\subsection{Benchmark parameter values}

In making relative welfare comparisons, we consider the three types of shocks defined in the previous subsection, namely: (i) asymmetric; (ii) idiosyncratic; and (iii) common. In order to illustrate the workings of the model by means of simulations, we initially report results for a benchmark set of parameters.

The parameter values used here follow previous work on calibrated models. While this means that our choice is constrained by available studies, the next subsection will more generally examine the sensitivity of relative stabilisation performance to changes in key parameters of the model. As discussed in the previous section, we assume that the supply schedule parameter $\alpha_{i}$ displays cross-country variation. Let $\alpha_{i}^{\prime} \equiv 1 / \alpha_{i}$ be its inverse, which represents the reaction of inflation to the output gap. Country-specific values of $\alpha_{i}^{\prime}$ hover around a central value which is chosen to be $\alpha^{\prime}=0.4$, as in Ball (1999). More concretely, we allow for two values for $\alpha_{i}^{\prime}$, a high value $\bar{\alpha}^{\prime}=0.45$ and a low value $\alpha^{\prime}=0.35$. Our benchmark value for $\varphi$ is 0.1 . Finally, we assume a common value for $\chi_{i}$ and $\chi$. For this parameter, we use Broadbent and Barro's (1997) estimate of 2.58, obtained using US data.

\subsection{Sensitivity analysis}

Sensitivity analysis is relevant for welfare analysis in the present paper. We have seen that, when the reference country is hit by aggregate supply shocks, neither the currency union nor autonomous monetary policy dominates its alternative. The present subsection assesses how sensitive is the relative performance between the two regimes to changes in key parameter values. In doing so, we first construct the ratio $C_{u h}=L_{h}^{u} / L_{h}$. This ratio expresses the value of reference country $h$ 's loss function under a currency union in proportion to that obtained under autonomous monetary policy. In both cases, we set this ratio to one at benchmark parameter values; that is, all values of the ratio are to be interpreted in relation to the benchmark case. 
One key parameter is the slope of the supply curve, $\alpha_{i}^{\prime}$, whose cross-country variation plays a major role in the present model. In this regard, we carry out sensitivity analysis with respect to the central value for this parameter, $\alpha^{\prime}$, and the difference between high and low alternative values for the latter, which we call simply spread $\equiv \bar{\alpha}^{\prime}-\underline{\alpha}^{\prime}$. In addition, we examine the effects of varying two other parameters, namely, the size of the reference country, $\varphi$, and the relative weight placed by the monetary authority on price stability in its loss function, $\chi$. We consider the three scenarios of common, idiosyncratic and asymmetric aggregate disturbances. As in Lane (2000), the analysis of the impact of changing these parameters is made conditional on the occurrence of these various types of shocks. In other words, we treat the size and asymmetry of shocks as exogenous, disregarding for tractability the possibility - discussed by Frankel and Rose (1998) - that the distribution of shocks and parameter values might both depend on the intensity of regional integration (which is different across monetary policy regimes).

Figures 1 through 4 show the relative welfare loss under aggregate supply shocks as measured by the ratio $C_{u h}$ for different types of reference countries, cross-country distribution of shocks and parameter values. In Figure 1, we consider the effects on relative stabilisation performance of varying $\alpha^{\prime}$ over the range [0.2-0.6]. An increase in $\alpha^{\prime}$ indicates a higher responsiveness of inflation to the output gap. In all cases considered, that is, for all combinations of reference countries, types of aggregate shocks and parameter values, we see that a higher $\alpha^{\prime}$ induces an increasingly better relative performance of country $h$ 's welfare under the currency union case. In the scenario of common shocks, both types of reference countries benefit from the homogenising effect of a rise in $\alpha^{\prime}$ - the central value of $\alpha_{i}^{\prime}$ - for a given value of spread. Under asymmetric shocks, the single monetary authority does not react, and thus member states' welfare is not affected by changes in $\alpha^{\prime}$. What in this case drives the improvement in $h$ 's welfare under the currency union relative to monetary autonomy 
is the standard increase in the loss function under monetary autonomy as the tradeoff between output and inflation becomes flatter. ${ }^{19}$ In light of the reference country's small size, this effect in place under asymmetric disturbances also plays a role in improving the relative performance of monetary union in the face of idiosyncratic shocks.

Figure 2 reports sensitivity analysis for spread over [0.05-0.35]. Under common aggregate productivity shocks, the differences between countries $h$ and $f$ are constrained to their sizes and the values of $\alpha_{i}^{\prime}$. The latter difference drives the contrasting results between Cases $\mathrm{H}$ and $\mathrm{L}$ in panel (a). The value of $h$ 's loss function (16) increases as $\alpha_{h}^{\prime}$ rises (as in Case $\mathrm{H}$ for increasing spread) and thus the tradeoff between output and inflation turns flatter; this contributes to lowering relative loss $C_{u h}$ in Case H. Following mutatis mutandis the same logic, reference country $h$ 's loss function under monetary autonomy drops with lower values of $\alpha_{h}^{\prime}$ (as in Case L for rising spread), therefore hampering the relative performance of currency union. The same factor drives the broadly similar results found for asymmetric shocks (once more, in the absence of changes in the loss function (23) under the currency union), while relative welfare is little sensitive to spread in the face of idiosyncratic disturbances.

In Figure 3, we vary $\varphi$ over the range [0.05-0.5]. An increase in $\varphi$ affects welfare only in the currency union. Under common shocks, as $\varphi$ rises the reference country benefits, relative to monetary autonomy, from increasing cross-country uniformity within the currency union. In panel (b), we see that under idiosyncratic shocks the improvements in the stabilisation properties of monetary union are steady only in Case H. We find that one factor behind this discrepancy is that, in the absence of shocks to country $f$, the magnitude of deviations in prices from target (which happens to have a large influence on country $h$ 's loss function) depends on the union-wide tradeoff between output

\footnotetext{
${ }^{19}$ To see this, note that the loss functions in (16) for autonomous monetary policy carries a factor $\chi /\left(\alpha_{i}^{2}+\chi\right)$, which is decreasing in $\alpha_{i}$ and thus increasing in $\alpha^{\prime}$.
} 
and inflation, $\alpha_{u}{ }^{20}$ More concretely, the flatter this tradeoff (which takes place for higher values of $\varphi$ under Case H) the smaller is country $h$ 's price level gap (in deviation from target) under the currency union, and thus the higher the relative welfare derived from the latter regime. Under asymmetric shocks, the monetary union is unresponsive to changes in country sizes, which is also the case for the monetary autonomy case regardless of the cross-country distribution of aggregate shocks. Therefore, $\varphi$ fails to impact relative welfare in this case.

Figure 4 reports sensitivity analysis for the central bank's preference parameter $\chi$ over the range [0.5-5]. ${ }^{21}$ Under common aggregate disturbances, a hike in $\chi$ is seen in panel (a) to improve relative welfare for reference countries in the currency union. The reason is simply that, under the current parameterisation, a higher weight on inflation implies a relatively improved ability of the single monetary policy to narrow the price level gap. For asymmetric aggregate productivity shocks, the improvement in member countries' welfare under the currency union is determined by exactly the same factor $\chi /\left(\alpha_{i}^{2}+\chi\right)$ discussed above for the impact of $\alpha^{\prime}$ (this time driven by changes in $\chi$ ), coupled with the lack of reaction under the monetary union. Finally, Figure 4 shows that, in the face of idiosyncratic disturbances, a higher value of $\chi$ reduces relative welfare under the currency union. This results from a muted offsetting response of the single monetary policy to the shock (due to country $h$ 's small size), coupled with the increasing weight on price stability. It is worth saying, though, that in panel (b) $C_{u h}$ appears to be somewhat unresponsive to changes in central bank preferences, in particular around benchmark parameter values.

In sum, we find that, in the face of aggregate supply shocks, a flatter

\footnotetext{
${ }^{20}$ More specifically, in this case the model implies that the price level gap equals $p_{h}=$ $\tilde{p}_{h}-\left[\left(\alpha_{f}-\alpha_{u}\right) /\left(\alpha_{f}-\alpha_{h}\right)\right]\left[\alpha_{u} /\left(\alpha_{u}^{2}+\chi\right)\right]$. This result is easiest to derive from the model presentation in the Appendix.

${ }^{21}$ Parameter $\chi$ is of central importance in models of monetary policy. For instance, Rogoff (1985) favours the appointment of a central banker with $\chi$ higher than its social value in order to achieve lower equilibrium inflation rates. It is worth saying that this result does not carry over to our model since we do not allow for inflation bias.
} 
tradeoff between output and inflation unambiguously contributes to an improvement of the currency union's stabilisation properties from the member state's point of view. In turn, a larger size also appears to have a favourable impact on the reference country's welfare under the currency union case, possibly with the exception of the scenario of a reference country that exhibits a steep output-inflation tradeoff and is mostly hit by idiosyncratic shocks. Small catching up countries thus should, on the one hand, be adversely affected by monetary union participation due to their initial size, while on the other benefit as they achieve real convergence via fast productivity growth. Our analysis sheds light on the role of two other determinants of the costs of renouncing monetary autonomy. Increased cross-country homogeneity in the slopes of the aggregate supply curve tends to favour currency union's member states with relatively steep tradeoffs between output and inflation. Finally, the stabilisation performance of member states is - barring idiosyncratic aggregate shocks - enhanced by monetary unions with a higher weight on price stability relative to output stability.

\section{Concluding remarks}

This paper examines the implications of monetary union for participating countries, focusing on the comparison of a catching up member state's welfare in a currency union relative to that under autonomous monetary policy. This comparison is carried out by means of sensitivity analysis with respect to benchmark parameter values. Our approach is motivated by the notion that it is important to better understand the determinants of stabilisation costs im-

plied by renouncing monetary autonomy, while at the same time recognising that a number of other factors play a key role in shaping a country's decision to enter a currency union. The latter factors prominently include the trade- 
enhancing effects of monetary union of the type found by Rose (2000) and other studies. $^{22}$

Given that members of a common currency area can be at different stages in the development process, it is worth allowing countries' supply conditions to differ inside the union, especially with regard to sectoral characteristics. For this reason, we focus on the study of scenarios in which the supply slope parameter is not uniform across the union, while sectoral productivity shocks are of the idiosyncratic or asymmetric type. The literature on productivitydriven Balassa-Samuelson effects has emphasised the important role played by sectoral shocks of the idiosyncratic or asymmetric type in driving catching up economies. The present study finds that sectoral productivity shocks on balance hamper the stabilisation performance of small member states joining a currency union.

We also assess the determinants of stabilisation costs of renouncing monetary autonomy in the face of aggregate supply disturbances. Our analysis shows that the output-inflation tradeoff and country size have welfare implications for a reference country. A flatter tradeoff between output and inflation is found to unambiguously contribute to an improvement of the currency union's stabilisation properties from the member state's point of view. In turn, a larger size also appears to have a rather favourable impact on the reference country's welfare under the currency union case, possibly excepting the case of a reference country mostly facing idiosyncratic disturbances while exhibiting a steep output-inflation tradeoff.

In performing sensitivity analysis, we change one parameter at a time. One could argue that the aggregate supply slope is related to country size because of both aspects' common link to trade openness. Indeed, some studies indicate that more open economies also display a flatter output-inflation tradeoff, while size is often seen as varying inversely with openness. In this regard, one could

\footnotetext{
${ }^{22}$ The related empirical literature includes Rose (2001), Engel and Rose (2002), Glick and Rose (2002), Flam and Nordstrom (2003) and Micco et al. (2004). For a meta-analysis of a currency union's effect on international trade, see Rose and Stanley (2005). Frankel and Rose (2002) and Bagella et al. (2004) investigate the impact of currency areas on output.
} 
be led to conclude that, for a more open member state, the beneficial impact of a flatter supply curve on the currency union's stabilisation properties is to a variable extent offset by a concomitant smaller size. However, we have shown that, in the case of a catching up country exhibiting high productivity growth in the tradable sector (and thereby subjected to exchange-rate appreciation pressures), the relationship between the slope of the output-inflation tradeoff and openness could well be positive rather than - as often expected - negative. For this reason, the combination of a flatter supply curve and a small size could prove detrimental to an open catching up country's participation in the monetary union. Reinforcing this view, fast tradable productivity growth could also be associated with the occurrence of either idiosyncratic or asymmetric sectoral productivity shocks. A number of countervailing factors exist notwithstanding, including the circumstances that catching up countries will increase their size over time and that the link between openness and size is not a linear one. With regard to the latter, it is sometimes acknowledged that size is influenced by many other determinants that have not only economic but also historical and socio-cultural roots (see, e.g., Alesina and and Spolaore, 2003).

Finally, our analysis sheds light on the role of two other determinants of the costs of renouncing autonomous monetary stabilisation. A narrower crosscountry spread in the slopes of the aggregate supply curve tends to favour currency union's member states with relatively steep tradeoffs between output and inflation. Moreover, currency unions that display a higher preference for price stability are found to also improve the stabilisation performance of member states, except in the event of idiosyncratic aggregate disturbances. 


\section{Appendix: Solving for domestic output and prices under the currency union}

This Appendix describes the solution for domestic output and prices in both countries under the currency union setup. As mentioned in the main text, the two countries' variables $y_{i}^{u}$ and $p_{i}^{u}$ (with $i=h ; f$ ) can be determined by solving the following four equations: two national supply curves (12) for $i=h ; f$, and the pair of expressions (20) and (21). These four equations can be more explicitly written in terms of the four unknowns as follows:

$$
\begin{aligned}
y_{h}-\bar{y}_{h} & =\alpha_{h}\left(p_{h}-\tilde{p}_{h}\right)+\varepsilon_{h} \\
y_{f}-\bar{y}_{f} & =\alpha_{f}\left(p_{f}-\tilde{p}_{f}\right)+\varepsilon_{f} \\
\varphi\left(y_{h}-\bar{y}_{h}\right)+(1-\varphi)\left(y_{f}-\bar{y}_{f}\right) & =\frac{\chi}{\alpha_{u}^{2}+\chi}\left[\varepsilon_{u}-\varphi(1-\varphi)\left(\alpha_{h}-\alpha_{f}\right) \tau_{e}\right] \\
\varphi\left(p_{h}-\tilde{p}_{h}\right)+(1-\varphi)\left(p_{f}-\tilde{p}_{f}\right) & =-\frac{\alpha_{u}}{\alpha_{u}^{2}+\chi}\left[\varepsilon_{u}-\varphi(1-\varphi)\left(\alpha_{h}-\alpha_{f}\right) \tau_{e}\right]
\end{aligned}
$$

where we have made the plausible assumption that $E\left(p_{i}\right)=\tilde{p}_{i}$ for $i=h ; f$.

Equations (A.1) through (A.4) deliver unique solutions for $y_{i}^{u}$ and $p_{i}^{u}$ under country-specific $\alpha_{i}$. Given our focus on the perspective of a catching up country, a scenario of uniform supply slopes $\alpha_{i}$ appears not to be very relevant. It is straightforward to see that the use of expressions (A.1) through (A.4) may not pin down $y_{i}^{u}$ and $p_{i}^{u}$ when $\alpha_{h}=\alpha_{f}=\alpha$. The use of logic however suggests some reasonable solutions under uniform supply slopes. In the case of common aggregate supply shocks, there is no difference between autonomous monetary policy and the currency union. Asymmetric aggregate productivity shocks do not motivate any reaction on the part of the currency union, compared with the case of monetary autonomy under which the central bank can instead partly offset the shock. The most difficult case is that of idiosyncratic aggregate supply shocks. Simple ideas of fairness (such as equitable distribu- 
tion of shock absorption across countries, or equality in the level of national welfare loss functions) do not produce any (positive) solution for $y_{i}^{u}$ and $p_{i}^{u}$. If the single monetary authority chooses the same deviations of national prices with respect to target, then output would deviate from its goal in ways that are country-specific. One possible solution is that of arguing that the monetary autonomy equilibrium still holds in light of its Pareto optimality. In any case, the scenario of common slopes is not so relevant for the present paper, which therefore concentrates on the case of country-specific output-inflation tradeoffs. 


\section{References}

[1] Alesina, A. and Barro, R. (2002). Currency unions. Quarterly Journal of Economics, 117, 409-436.

[2] Alesina, A. and Spolaore, E. (2003). The Size of Nations. Cambridge, MA: MIT Press.

[3] Alesina, A., Spolaore, E. and Wacziarg, R. (2005). Trade, growth and the size of countries. In P. Aghion and S. Durlauf (eds.), Handbook of Economic Growth. Amsterdam: North Holland.

[4] Bagella, M., Becchetti, L. and Hasan, I. (2004). The anticipated and concurring effects of the EMU: Exchange rate volatility, institutions and growth. Journal of International Money and Finance, 23, 1053-1080.

[5] Ball, L. (1999). Policy rules for open economies. In J. Taylor (ed.), Monetary Policy Rules. Chicago: University of Chicago Press.

[6] Barry, F. (2001). Openness, the Phillips curve and the cost of relinquishing the currency. Centre for Economic Research Working Paper no. 5, University College Dublin.

[7] Benigno, P. (2004). Optimal monetary policy in a currency area. Journal of International Economics, 63, 293-320.

[8] Burstein, A., Neves, J. and Rebelo, S. (2003). Distribution costs and real exchange rate dynamics during exchange-rate-based stabilizations. Journal of Monetary Economics, 50, 1189-1214.

[9] Burstein, A., Eichenbaum, M. and Rebelo, S. (2005). Large devaluations and the real exchange rate. Journal of Political Economy, 113, 742-784.

[10] Ca' Zorzi, M., De Santis, R. and Zampolli, F. (2005). Welfare implications of joining a currency union. ECB Working Paper no. 445. 
[11] Calvo, G. and Reinhart, C. (2002). Fear of floating. Quarterly Journal of Economics, 117, 379-408.

[12] De Broeck, M. and Slok, T. (2001). Interpreting real exchange rate movements in transition countries. IMF Working Paper no. 01/56.

[13] Devereux, M. (1999). Real exchange rate trends and growth: A model of East Asia. Review of International Economics, 7, 509-521.

[14] Devereux, M. (2003). Macroeconomic Analysis of EU accession under alternative monetary policies. Journal of Common Market Studies, 41, 941-964.

[15] Egert, B., Drine, I., Lommatzsch, K. and Rault, C. (2003). The BalassaSamuelson effect in Central and Eastern Europe: Myth or reality? Journal of Comparative Economics, 31, 552-572.

[16] Fischer, S. (2001). Exchange rate regimes: Is the bipolar view correct? Journal of Economic Perspectives, 15, 3-24.

[17] Frankel, J. and Rose, A. (1998). The endogeneity of the optimum currency area criteria. Economic Journal, 108, 1009-1025.

[18] Flam, H. and Nordstrom, H. (2003). Trade volume effects of the euro: Aggregate and sector estimates. Institute for International Economic Studies Working Paper.

[19] Halpern, L. and Wyplosz, C. (2001). Economic transformation and real exchange rates in the 2000s: The Balassa-Samuelson connection. Economic Survey of Europe no. 1, 227-239.

[20] Ito, T., Isard, P. and Symansky, S. (1999). Economic growth and real exchange rate: An overview of the Balassa-Samuelson hypothesis in Asia. In Ito, T. and A. Krueger (eds.), Changes in Exchange Rates in Rapidly 
Developing Countries: Theory, Practice, and Policy Issues. Chicago: University of Chicago Press.

[21] Jiménez-Rodríguez, R. and Sánchez, M. (2005). Oil price shocks and real GDP growth: Empirical evidence for some OECD countries. Applied Economics, 37, 201-228.

[22] Lane, P. (1997). Inflation in open economies. Journal of International Economics, 42, 327-347.

[23] Lane, P. (2000). Asymmetric shocks and monetary policy in a currency union. Scandinavian Journal of Economics, 102, 585-604.

[24] MacDonald, R. and Wójcik, C. (2004). Catching up: The role of demand, supply and regulated price effects on the real exchange rates of four accession countries. Economics of Transition, 12, 153-179.

[25] Micco, A., Stein, E. and Ordóñez, G. (2003). The currency union effect on trade: Early evidence from EMU. Economic Policy, 18, 316-356.

[26] Mihaljek, D. and Klau, M. (2004). The Balassa-Samuelson effect in Central Europe: A disaggregated analysis. Comparative Economic Studies, $46,63-94$.

[27] Natalucci, F. and Ravenna, F. (2002). The road to adopting the euro: monetary policy and exchange rate regimes in EU candidate countries. International Finance Discussion Paper no. 741, Board of Governors of the Federal Reserve System.

[28] Razin, A. and Loungani, P. (2005). Globalization and disinflation. Mimeo, University of Tel Aviv and Cornell University / IMF.

[29] Razin, A. (2005). Aggregate supply and potential output. Journal of Money, Credit, and Banking, 34, 450-468. 
[30] Reinhart, C. and Rogoff, K. (2004). The modern history of exchange rate arrangements: A reinterpretation. Quarterly Journal of Economics, 119, $1-48$.

[31] Rogoff, K. (1985). The optimal degree of commitment to an intermediate monetary target. Quarterly Journal of Economics, 100, 1169-1190.

[32] Romer, D. (1993). Openness and inflation: Theory and evidence. Quarterly Journal of Economics, 108, 869-903.

[33] Rose, A. (2000). One money, one market: Estimating the effect of common currencies on trade. Economic Policy, 15, 7-46.

[34] Rose, A. and Stanley, T. (2005). A meta-analysis of the effect of common currencies on international trade. Journal of Economic Surveys, 19, 347365 .

[35] Sánchez, M. (2005a). Is time ripe for a currency union in Emerging East Asia?: The role of monetary stabilisation. ECB Working Paper no. 567.

[36] Sánchez, M. (2005b). Monetary stabilisation in a currency union of small open economies. Mimeo. European Central Bank, Frankfurt.

[37] Sinn, H. and Reutter, M. (2001). The minimum inflation rate for Euroland. NBER Working Paper no. 8085.

[38] Temple, J. (2002). Openness, inflation and the Phillips curve: A puzzle. Journal of Money, Credit, and Banking, 34, 450-468.

[39] Woodford, M. (2003). Interest and prices. Princeton, NJ: Princeton University Press. 

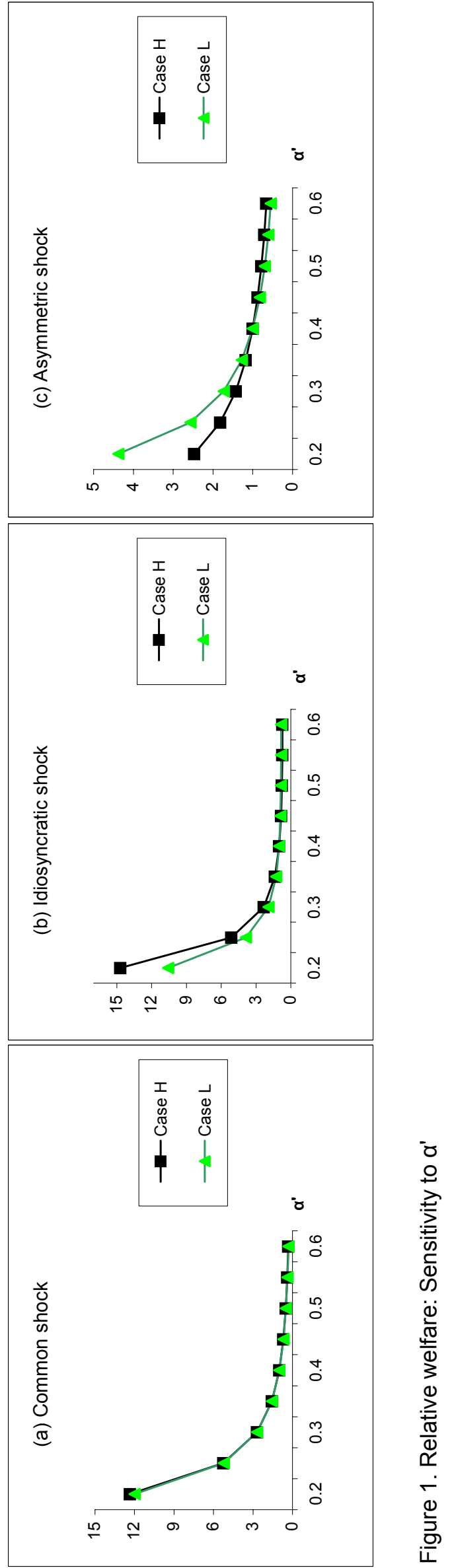

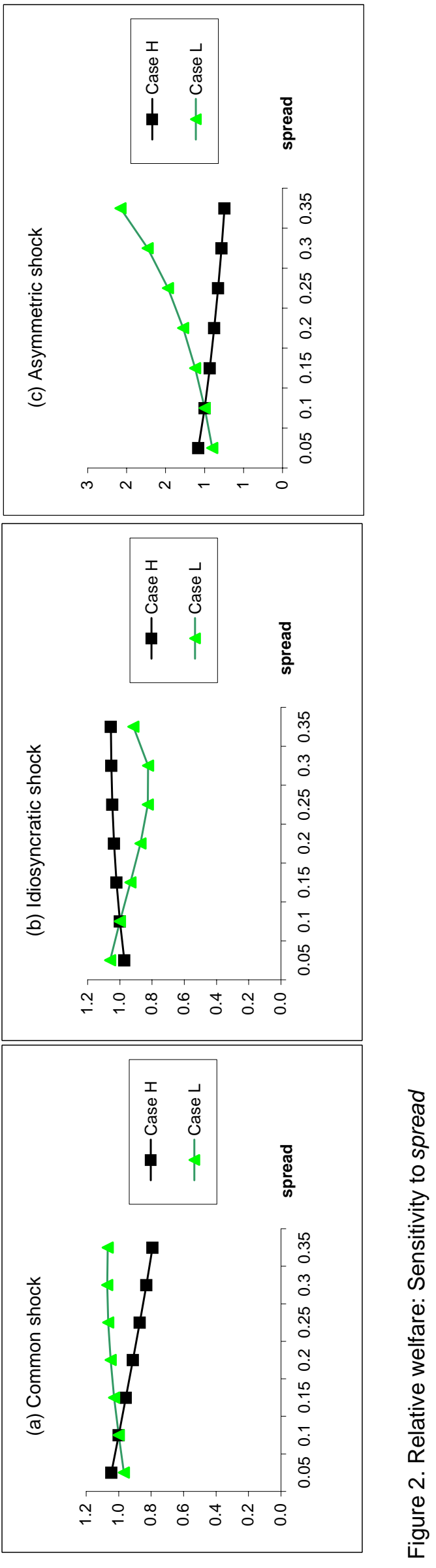

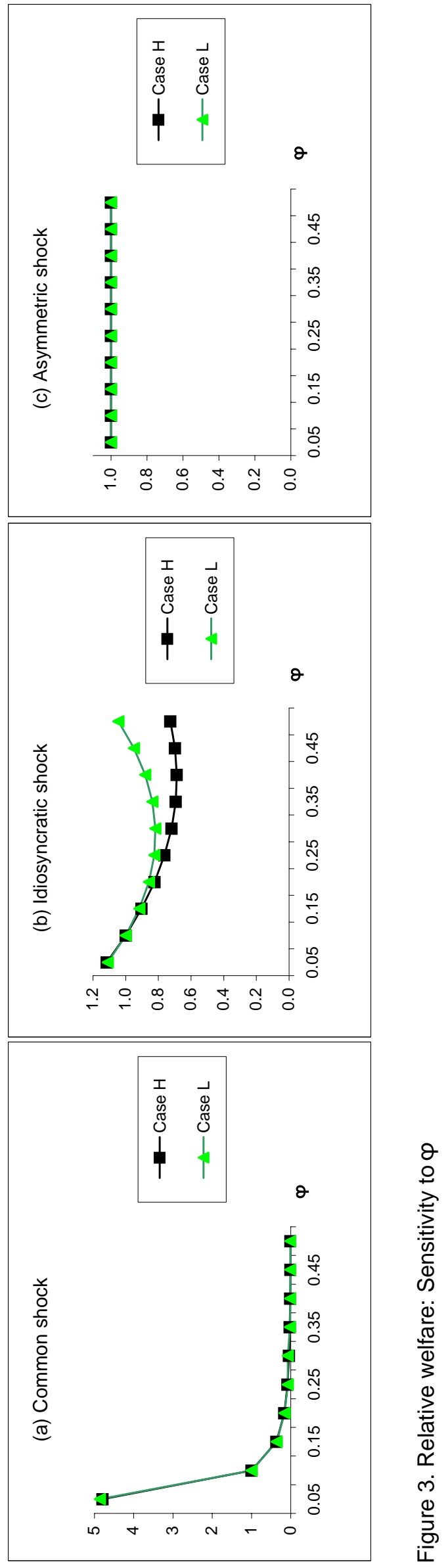

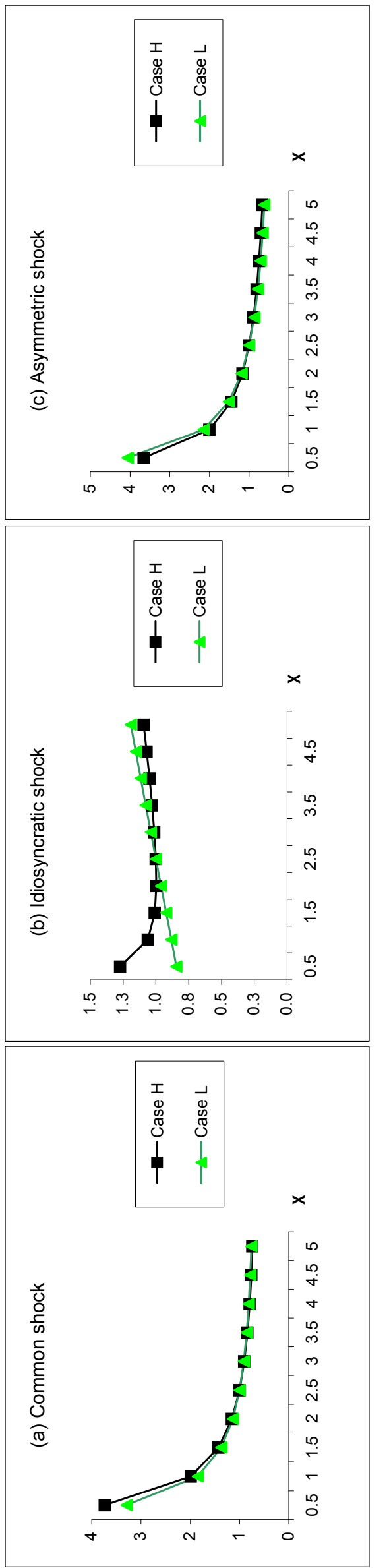

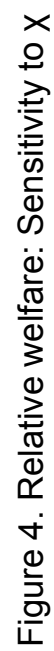




\section{European Central Bank Working Paper Series}

For a complete list of Working Papers published by the ECB, please visit the ECB's website (http://www.ecb.int)

585 "Are specific skills an obstacle to labor market adjustment? Theory and an application to the EU enlargement” by A. Lamo, J. Messina and E. Wasmer, February 2006.

586 "A method to generate structural impulse-responses for measuring the effects of shocks in structural macro models" by A. Beyer and R. E. A. Farmer, February 2006.

587 “Determinants of business cycle synchronisation across euro area countries" by U. Böwer and C. Guillemineau, February 2006.

588 "Rational inattention, inflation developments and perceptions after the euro cash changeover" by M. Ehrmann, February 2006.

589 "Forecasting economic aggregates by disaggregates" by D. F. Hendry and K. Hubrich, February 2006.

590 "The pecking order of cross-border investment" by C. Daude and M. Fratzscher, February 2006.

591 "Cointegration in panel data with breaks and cross-section dependence" by A. Banerjee and J. L. Carrion-i-Silvestre, February 2006.

592 "Non-linear dynamics in the euro area demand for MI" by A. Calza and A. Zaghini, February 2006.

593 “Robustifying learnability” by R. J. Tetlow and P. von zur Muehlen, February 2006.

594 “The euro's trade effects” by R. Baldwin, comments by J. A. Frankel and J. Melitz, March 2006

595 "Trends and cycles in the euro area: how much heterogeneity and should we worry about it?" by D. Giannone and L. Reichlin, comments by B. E. Sørensen and M. McCarthy, March 2006.

596 "The effects of EMU on structural reforms in labour and product markets" by R. Duval and J. Elmeskov, comments by S. Nickell and J. F. Jimeno, March 2006.

597 "Price setting and inflation persistence: did EMU matter?" by I. Angeloni, L. Aucremanne, M. Ciccarelli, comments by W. T. Dickens and T. Yates, March 2006.

598 "The impact of the euro on financial markets" by L. Cappiello, P. Hördahl, A. Kadareja and S. Manganelli, comments by X. Vives and B. Gerard, March 2006.

599 "What effects is EMU having on the euro area and its Member Countries? An overview" by F. P. Mongelli and J. L. Vega, March 2006.

600 “A speed limit monetary policy rule for the euro area” by L. Stracca, April 2006.

601 "Excess burden and the cost of inefficiency in public services provision" by A. Afonso and V. Gaspar, April 2006. 
602 "Job flow dynamics and firing restrictions: evidence from Europe" by J. Messina and G. Vallanti, April 2006.

603 "Estimating multi-country VAR models" by F. Canova and M. Ciccarelli, April 2006.

604 "A dynamic model of settlement" by T. Koeppl, C. Monnet and T. Temzelides, April 2006.

605 “(Un)Predictability and macroeconomic stability” by A. D’Agostino, D. Giannone and P. Surico, April 2006.

606 "Measuring the importance of the uniform nonsynchronization hypothesis" by D. A. Dias, C. Robalo Marques and J. M. C. Santos Silva, April 2006.

607 "Price setting behaviour in the Netherlands: results of a survey" by M. Hoeberichts and A. Stokman, April 2006.

608 "How does information affect the comovement between interest rates and exchange rates?" by M. Sánchez, April 2006.

609 "The elusive welfare economics of price stability as a monetary policy objective: why New Keynesian central bankers should validate core inflation" by W. H. Buiter, April 2006.

610 "Real-time model uncertainty in the United States: the Fed from 1996-2003" by R. J. Tetlow and B. Ironside, April 2006.

61I "Monetary policy, determinacy, and learnability in the open economy" by J. Bullard and E. Schaling, April 2006.

612 "Optimal fiscal and monetary policy in a medium-scale macroeconomic model" by S. Schmitt-Grohé and M. Uribe, April 2006.

613 "Welfare-based monetary policy rules in an estimated DSGE model of the US economy" by M. Juillard, P. Karam, D. Laxton and P. Pesenti, April 2006.

6I4 "Expenditure switching vs. real exchange rate stabilization: competing objectives for exchange rate policy" by M. B. Devereux and C. Engel, April 2006.

615 "Quantitative goals for monetary policy" by A. Fatás, I. Mihov and A. K. Rose, April 2006.

616 "Global financial transmission of monetary policy shocks" by M. Ehrmann and M. Fratzscher, April 2006.

617 "New survey evidence on the pricing behaviour of Luxembourg firms" by P. Lünnemann and T. Y. Mathä, May 2006.

618 "The patterns and determinants of price setting in the Belgian industry" by D. Cornille and M. Dossche, May 2006.

619 "Cyclical inflation divergence and different labor market institutions in the EMU" by A. Campolmi and E. Faia, May 2006. 
620 "Does fiscal policy matter for the trade account? A panel cointegration study" by K. Funke and C. Nickel, May 2006.

621 "Assessing predetermined expectations in the standard sticky-price model: a Bayesian approach" by P. Welz, May 2006.

622 "Short-term forecasts of euro area real GDP growth: an assessment of real-time performance based on vintage data" by M. Diron, May 2006.

623 "Human capital, the structure of production, and growth" by A. Ciccone and E. Papaioannou, May 2006.

624 "Foreign reserves management subject to a policy objective" by J. Coche, M. Koivu, K. Nyholm and V. Poikonen, May 2006.

625 "Sectoral explanations of employment in Europe: the role of services" by A. D'Agostino, R. Serafini and M. Ward-Warmedinger, May 2006.

626 "Financial integration, international portfolio choice and the European Monetary Union" by R. A. De Santis and B. Gérard, May 2006.

627 "Euro area banking sector integration: using hierarchical cluster analysis techniques" by C. Kok Sørensen, J. M. Puigvert Gutiérrez, May 2006.

628 "Long-run money demand in the new EU Member States with exchange rate effects" by C. Dreger, H.-E. Reimers and B. Roffia, May 2006.

629 "A market microstructure analysis of foreign exchange intervention" by P. Vitale, May 2006.

630 “Implications of monetary union for catching-up member states” by M. Sánchez, May 2006. 
